LITERATURA 



\section{LO SUBLIME EN LA HOMOPOÉTICA DE VICENTE ALEIXANDRE}

Ronald Campos López

\section{(c) $\underset{\mathrm{BY}}{(\Theta \mathrm{NO}} \mathrm{ND}$}

Esta obra está bajo una licencia Creative Commons

Reconocimiento-No Comercial-Sin Obra Derivada 



\title{
LO SUBLIME EN LA HOMOPOÉTICA DE VICENTE ALEIXANDRE
}

\author{
THE SUBLIME IN THE HOMOPOETIC OF \\ VICENTE ALEIXANDRE
}

Ronald Campos López.

\begin{abstract}
RESUMEN
Este artículo pretende desarrollar un trabajo de des-ocultación de la homopoética de Vicente Aleixandre, analizando símbolos, visiones e imágenes visionarias como expresiones de un homoerotismo, donde las experiencias sublimes predominan y definen a los amantes líricos homosexuales y el ambiente cósmico, contextual e íntimo. Para esta lectura hermenéutica, se analizan los poemas: "Se querían", "Mano entregada" y "No busques, no". Se concluye que lo sublime participa significativamente en la consolidación de la homopoética aleixandrina, primero, al manifestarse como ese intento por convertir elementos y vivencias cotidianas homoeróticas en un algo que eleva y transforma al sujeto lírico por medio de la imaginación; segundo, al definir, como recursos de homotextualización, el juego de luces y sombras, la ambigüedad, el hermetismo, el desdoblamiento, los límites de lo macrocósmico y lo microcósmico, los simbolismos de la sangre, las imágenes visionarias surrealistas, las visiones fenomenológicas e imaginativas, una conciencia ecológica, la generación de sinestesias, la fragmentación de la identidad y confesiones homoeróticas, la antífrasis y la lítote.

Palabras clave: poesía española, Vicente Aleixandre, homopoética, lo sublime, homotextualización.
\end{abstract}

\begin{abstract}
This article aims to develop a "des-concealment" work of the "homopoetics" of Vicente Aleixandre. For this, symbols, visions and visionary images are analyzed as expressions of a homoeroticism, where sublime experiences predominate and define to the lyrical homosexual lovers and the cosmic, contextual and intimate environment. The poems "Se querían", "Mano entregada" and "No busques, no" are interpreted into a hermeneutical reading. This concludes that the sublime significantly participates in the consolidation of Aleixandre's "homopoetics" in two ways. Firstly, the sublime is manifested as an attempt to convert daily homoerotic elements and experiences into something that elevates and transforms the lyrical subject through imagination. Secondly, the sublime defines, as "homotexting" resources, the play with light and shadow, the ambiguity, the hermetic, the splitting, the macro-cosmic and micro-cosmic limits, the blood symbolisms, the surrealist visionary images, the phenomenological and imaginative visions, an ecological awareness, the synesthesia generating, the homoerotic identity and confessions fragmentation, the antiphrasis and the litotes.

Key words: spanish poetry, Vicente Aleixandre, homopoetic, the sublime, homotexting.
\end{abstract}

Dr. Ronald Campos López. Profesor interino del Departamento de Literatura de la Universidad de Costa Rica. Correo electrónico: roncalo1125@gmail.com

Recepción: 15- 04- 2017

Aceptación: 16- 05- 2017 


\section{Hacia la homopoética de Vicente Aleixandre}

Tal y como afirma Mateos-Miera (2003), en algunos textos de Luis Cernuda, Federico García Lorca, Emilio Prados o Vicente Aleixandre, la identidad homosexual únicamente se puede reconocer a través de un trabajo de des-ocultación.

El discurso decadentista finisecular del XIX y las representaciones hegemónicas de lo homosexual como delito, patología, depravación moral y pecado mortal, así como sus consecuentes soluciones (la sentencia penal, la cura, el rechazo y la condena espiritual, respectivamente) (Dyer, 1993; Mira, 2004; Campos, 2016), tuvieron su repercusión no solo en el desarrollo de la literatura española de principios del siglo XX (Phillipps-López, 2002), sino también en el contexto sociocultural y político previo y posterior al franquismo.

Ante esta tensión y el temor de llegar a ser estereotipado y desautorizado por el habitus homofóbico (las estructuras que construyen la experiencia homofóbica, generan dicha realidad y buscan garantizar siempre que el homosexual comporte abyección, estigma y exclusión social) (Mira, 2004; Campos, 2016), los poetas homosexuales de la Generación del 27 fueron víctimas de su autorrepresión frente al entorno social y político intolerante, y posiblemente llegaron a sentirse, parafraseando el título de Prados (1971), cuerpos perseguidos que no podían expresarse completa ni libremente. De ahí que hayan ocultado o enmascarado su condición en sus textos y obliguen aún hoy a los lectores a descifrar su expresión homoerótica, a través de un palimpsesto de signos verbales que materializan ese drama de la imposibilidad de decirse (Mateos-Miera, 2003).

Valiéndose de los indicios o referencias claras sobre la homosexualidad de García Lorca, Cernuda y Prados, Mateos-Miera (2003) indaga la progresiva visibilidad y afirmación del cuerpo homoerótico, así como la ruptura con estereotipos dominantes instaurados por los discursos decimonónicos sobre la homosexualidad, en textos de aquellos tres poetas. Excluye de su análisis, empero, todo abordaje con respecto a textos de Aleixandre, ya que no lo considera poeta de expresión homoerótica, pues su condición homosexual nunca fue explícitamente revelada; afirma que, hasta ese momento, únicamente se cuenta con leyendas orales o testimonios personales y ninguna investigación ni estudio que aclare dicho silencio enigmático. Curiosamente, Mateos-Miera parte de estas mismas leyendas para ubicar, en las antípodas de Cernuda y su reconocimiento como homosexual, a "un casi olvidado Aleixandre cuya escasa presencia en el actual panorama poético acaso tenga que ver con la máscara que adoptó frente al mismo problema" (2003, p. 82).

La limitación objetiva señalada por Mateos-Miera sobre la homosexualidad de Aleixandre, sin embargo, es resuelta por Calderón, quien en 2016 publica la primera biografía completa sobre el poeta sevillano, rigurosamente documentada a partir de sus cartas y otros escritos inéditos ${ }^{1}$. En ella, entre otros aspectos de su vida pública y privada, Calderón revela la bisexualidad de Aleixandre.

Dicha biografía no viene sino a aportar las pruebas objetivas para aquellos que, como Mateos-Miera (2003), encontraban limitaciones (pareciera que políticas) para hablar sobre la poesía homoerótica aleixandrina. No obstante, en esta, la homopoética - concepto acuñado por Losada (2013) para referirse a la escritura homoerótica - siempre ha sido evidente a través de recursos propios de una homotextualización; - dentro de los que menciona el mismo Losada - por ejemplo: el desdoblamiento, los añorados paisajes de la juventud, los ambientes oníricos, el frenético amor ante el paso del tiempo, la fugacidad perturbadora, el miedo, el 
silencio, la meditación sobre la vida, el tono confesional y autobiográfico, pero también el vitalismo, la amistad, la reflexión sobre la escritura poética, el deseo de libertad y la falta de compromiso (con alguna forma establecida de pensar, patrón cultural o modo de interpretación artística). Tales recursos, junto a algunos rasgos estilísticos, simbólicos y expresivos que Bousoño $(1977,1985)$ ha analizado, materializan el enmascaramiento y la sugerencia, la latente dicibilidad de este cuerpo perseguido, temeroso de la injuria, marginado y recluido no solo por su inestable salud, sino también por la imposibilidad de desvelar parte de su orientación sexual y valores erótico-afectivos.

Por lo anterior, este estudio, más allá de cualquier comprobación documental sobre la orientación sexual del autor empírico, pretende desarrollar un trabajo de des-ocultación (Mateos-Miera, 2003), analizando símbolos, visiones e imágenes visionarias como expresiones de un homoerotismo, donde las experiencias sublimes predominan y definen no solo a los amantes líricos homosexuales, sino también el ambiente cósmico, contextual e íntimo. Para esta lectura hermenéutica, se analizan tres poemas: "No busques, no" y "Se querían", de $L a$ destrucción o el amor; y "Mano entregada", de Historia del corazón. Conforme se analicen los textos, se brindará, asimismo de manera tangencial, una descripción de las figuras estilísticas, según la tipología de Fernández (1979).

De La destrucción o el amor se eligieron los susodichos poemas, ya que este poemario, junto a Ámbito, Espadas como labios y Sombra del paraíso, pertenece, según Bousoño (1977), a la primera etapa de producción de Aleixandre, en la cual predomina una visión pesimista del ser humano; por eso, se recurre temáticamente a la imperfección, el dolor, la angustia y la fragilidad, y, como contrarrespuesta, se metaforiza el deseo de unión con la naturaleza, una existencia pura y elemental, en términos místico-panteístas. En esta etapa, la pasión amorosa se (con)funde con una pasión por la muerte liberadora y el nacimiento en el otro. Por otra parte, Bousoño (1977) ubica a Historia del corazón y En un vasto dominio en una segunda etapa caracterizada por el abandono del surrealismo y una visión positiva del ser humano, engrandecido por la solidaridad. Como muestra de esta segunda etapa se ha seleccionado "Mano entregada". Pérez (2001) se refiere específicamente a este poema como un texto donde el amor se propaga en el roce, a modo de un río variado (de sangre, silencio, secreto y voces) hasta convertirse en una sola voz; ante el contacto, el cuerpo del amante se vuelve espacio para ser poblado, de ahí la sensualidad de imágenes corpóreo-telúricas que construyen la plenitud serena compartida. El propio Aleixandre pensaba que "Mano entregada" ofrecía "una visión del amor como símbolo trascendido de solidaridad de los hombres, ante los «términos» de su vivir" (1976, p. 195).

Sin duda, será el amor el tema que permita abordar la homopoética en la muestra textual. Por su parte, Pérez (2001) ha recorrido, a través de la obra aleixandrina, el asunto del amor como fuerza poética y metafísica, en términos místicos, panteístas y eróticos, pues se defiende la noción del amor como sustancia de vida y arte, y como trascendencia de los límites concretos para adentrarse en el mundo cósmico del ser.

\section{De lo sublime y la imaginación simbólica}

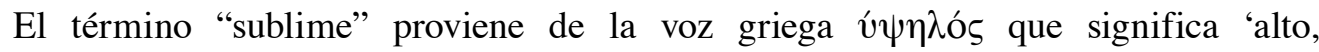
elevado, magnífico'. Por eso, lo sublime corresponde a aquella vivencia extraordinariamente sorprendente y transformadora, que solo puede hallarse en el pensamiento y expresarse con 
simplicidad, o bien por medio de metáforas, imágenes o visiones. La idea clave de lo sublime radica en la capacidad o potencia de transformación por la cual se convierte un elemento en un algo superior, más elevado y, por tanto, mejorado. El producto sublimado no es distinto del anterior: su estado es cuanto se ha transformado, pero esencialmente sigue siendo el mismo objeto (Addison, 1994).

La experiencia sublime ha de ocurrir con base en una emoción objetiva que proviene de una pasión y esta, a su vez, de la imaginación. Por eso, las figuras con que se consigue una composición y expresión sublimes siempre son retóricas, en especial cuando tales logran ser trasladadas a un lenguaje visual.

Desde el punto de vista cartesiano, el ser humano está compuesto por dos esferas: la superior, dominada por el entendimiento racional; y la inferior, dominio de las pasiones provocadas por los sentidos. En la intersección de ambas (la idea superior o inspiración artística, y la inferior o materialización de esa idea en objeto artístico) se sitúa el arte como tal. Según Addison (1994), en la esfera superior se encuentran el juicio y el pensamiento; en la inferior, los deleites sensuales estimulados por todos los sentidos excepto la vista; de modo que existiría una esfera intermedia a que él llama imaginación, donde se encuentran todos los productos de las percepciones visuales. Addison considera, por ende, a la vista como el más perfecto de los sentidos porque, en su opinión, es el único sentido que no precisa contacto con el objeto para aprehenderlo. De ahí que defina los placeres de la imaginación como aquellos dados por los objetos visibles.

En esta dirección, Addison (1994) divide en dos clases los placeres de la imaginación según sus cualidades. Por un lado, las cualidades primarias son aquellas totalmente inseparables de un cuerpo, sea cual fuera el estado en que se encuentre, y de la naturaleza que las conserva de manera constante en todas las alteraciones y cambios, que dicho cuerpo experimente por razón de una fuerza mayor ejercida sobre él. Cualidades primarias serían, pues, la solidez, el volumen, la forma, el reposo y el movimiento. Por otra parte, las cualidades secundarias tales como: los colores, el gusto, los sonidos, entre otros, resultan modificaciones de la materia de los cuerpos (de sus cualidades primarias) producidas por la percepción; por eso, son potencias que producen en el espectador diversas sensaciones y configuran las ideas que la mente se forma del objeto. En fin, las cualidades primarias son objetivas, ya que existen al margen del sujeto y son percibidas por el entendimiento; mientras que las secundarias constituyen sensaciones subjetivas proyectadas por la imaginación.

El ser humano disfruta de paisajes naturales que le permitan perderse en la inmensidad. Estos nunca están limitados y no se agradan por su tamaño, capaz de llenar totalmente la imaginación, sino por su eventual carácter sobrenatural. Así, la sublimidad queda desligada de la imitación de lo natural, ya que en ningún caso pretende captar la realidad, sino más bien distinguir imaginariamente su esencia puesto que, si la misión de imitar la naturaleza es exterior, la imaginación en un nivel interior transforma lo observado. En consecuencia, la experiencia sublime y la imaginación siempre se identificarían con una revelación subjetiva, poética, de sumo significado para un sujeto, ya que la experiencia sublime como la imaginación simbólica, al ser lenguaje y, por ende, subjetividad trascendental o intersubjetiva, no constituirían una mera copia de una realidad cósica o relacional abstracta, sino que actuarían como una evocación, expresión, representación, comprensión, transcripción o interpretación creativa de una infraestructura, vivencia o realidad profunda (Durand, 1971). Así pues, lo sublime como lo imaginativo reconciliarían los contrarios y funcionarían como 
intermediarios entre lo humano y lo otro, lo real, dado que ambos, gracias al lenguaje, se basan en el conocimiento simbólico y la no-distinción entre el ser y el cosmos, superan los planteamientos dualistas del mundo material e ideal, y organizan una jerarquía axiológica y una ontológica intermedia que garantiza la coincidencia de los opuestos.

\section{El trío imaginativo de referencia: Imagen visionaria, visión y símbolo}

De acuerdo con Bousoño (1985), la imagen visionaria, la visión y el símbolo tienen en común la opacidad o plasticidad, la función intuitivamente emotiva y la borrosidad de los ingredientes razonables, cuando estos son extraídos a través de un análisis extraestético de la masa emocional que los oculta y supone. Como se verá, es posible considerar este trío imaginativo como mediador o conductor de la experiencia sublime.

Antes de definir la imagen visionaria es necesario aclarar el concepto de imagen tradicional, para así clarificar mejor la primera. La imagen tradicional exhibe una estructura racionalista que difiere radicalmente de la estructura irracional que manifiestan las imágenes peculiares de la poesía vanguardista o contemporánea. Según Bousoño (1985), existen tres posibilidades de imágenes tradicionales: 1) las engendradas sobre la semejanza física que media entre el plano real y el evocado; 2) las justificadas en la semejanza moral o espiritual de dos seres; 3) las emanadas de la identidad en el valor con que dos miembros, el real y el evocado, se presentan. Las tres posibilidades coinciden en un punto: la semejanza entre sus dos planos se basa siempre en una condición objetiva (física, moral o axiológica) que es previa al sujeto contemplador, pues los valores son cualidades objetivas de los seres.

En la imagen visionaria se tendrá por iguales a los términos real y evocado, no porque objetivamente se parezcan en su figura material, en su configuración moral o en su valor; sino porque despiertan en el lector un sentimiento parejo, relativamente universal; para ello, la imagen visionaria debe caracterizarse por su irracionalidad y subjetivismo. Así, ella pone en crisis el racionalismo estricto de los siglos anteriores.

Por otra parte, la visión no es evidentemente una metáfora. En las visiones la cualidad o función irreal que se atribuye al objeto real es un aparato de afecciones, pues este tiene como única misión la de producir una impresión. La cualidad irreal no pretende sino impresionar de un modo particular, tratando de conseguir una pura irrealidad que no se sabe ni cómo ni por qué resulta emocionante. Así pues, a la visión corresponderá una atribución de cualidades o de funciones imposibles a un objeto, y cuya significación radica en su carácter afectivo.

Por último, Bousoño (1985) afirma que el símbolo puede ocupar la totalidad de un poema o una parte considerable de él, pero puede también privarse de tal extensión. El plano real no aparece en la intuición, que es desde sí puramente emotivo, sino en el análisis extraestético de la intuición. De ahí que el símbolo sea siempre un foco de indeterminaciones y entrevistas penumbras.

Estos tres conceptos, pues, ayudan a Bousoño (1985) a describir la intensificación del fenómeno visionario. Entre los recursos utilizados por la poesía contemporánea para la formación de imágenes visionarias, se tiene el recurso de componer un texto lírico sobre una sola imagen. Esta unicidad de principio a fin permite adentrarse en las zonas abisales de la psique del sujeto lírico, aquellas que serán más intensamente visionarias de sus manifestaciones poéticas, porque la expresión normal del inconsciente es generalmente de esa índole. Este planteamiento se sustenta en el análisis de los sueños, ya que las representaciones oníricas 
utilizan no solo símbolos, sino también las visiones e imágenes visionarias. De ahí que tres maneras de intensificar este proceso sean: 1) las visiones en el sueño, puesto que es indudable que los sueños adoptan muchas veces el aspecto de verdaderas visiones, como cuando se atribuyen cualidades irreales (tamaño cósmico) a un cuerpo humano; 2) los símbolos en el sueño, cuando el plano real que late bajo el contenido manifiesto es de índole espiritual y el sueño lo representa por medio de imágenes visuales; 3) las imágenes visionarias en el sueño, cuando no hay en absoluto una semejanza objetiva entre las dos esferas comparadas, tan solo un parecido difuso que es precisamente lo que permite la universalidad imaginativa de la poesía, frente a la posible individualidad de las imágenes del sueño.

\section{Análisis textual}

\section{1 "Se querían"}

Se querían.

Sufrían por la luz, labios azules en la madrugada,

labios saliendo de la noche dura,

labios partidos, sangre, ¿sangre dónde?

Se querían en un lecho navío, mitad noche, mitad luz.

Se querían como las flores a las espinas hondas,

a esa amorosa gema del amarillo nuevo,

cuando los rostros giran melancólicamente,

giralunas que brillan recibiendo aquel beso.

Se querían de noche, cuando los perros hondos

laten bajo la tierra y los valles se estiran

como lomos arcaicos que se sienten repasados:

caricia, seda, mano, luna que llega y toca.

Se querían de amor entre la madrugada,

entre las duras piedras cerradas de la noche,

duras como los cuerpos helados por las horas,

duras como los besos de diente a diente sólo.

Se querían de día, playa que va creciendo, ondas que por los pies acarician los muslos, cuerpos que se levantan de la tierra y flotando...

Se querían de día, sobre el mar, bajo el cielo.

Mediodía perfecto, se querían tan íntimos, mar altísimo y joven, intimidad extensa, soledad de lo vivo, horizontes remotos ligados como cuerpos en soledad cantando.

Amando. Se querían como la luna lúcida, como ese mar redondo que se aplica a ese rostro, dulce eclipse de agua, mejilla oscurecida, donde los peces rojos van y vienen sin música.

Día, noche, ponientes, madrugadas, espacios, 
Si se parte de que el enfoque del poema es fundamentalmente un encuentro homoerótico, un tema tabú en el momento de publicación del texto (1932, en Poesía española. Antología 1915-1931, la primera antología de Gerardo Diego sobre la poesía del 27), la utilización del desdoblamiento en tercera persona permite tácticamente al sujeto lírico un mayor grado de impersonalidad y, por tanto, enmascarar, encubrir al yo (López-Casanova, 1994). Esta tercera persona plural está marcada desde el sintagma verbal "se querían". Este se presenta tanto en el título de tipo vivencial (López-Casanova, 1994), como en la anáfora (vv. 1, $6,10,14,18$ ) o el paralelismo (vv. 22, 26, 34) en cada una de las ocho estrofas. La recurrencia a la tercera persona plural en dicho sintagma permite interpretar simultáneamente, primero, un alejamiento del sujeto lírico con respecto a la vivencia pasional de esos ellos líricos; pero, en segundo lugar, también, una identificación solapada con esta pasión. Esta distancia pragmática del sujeto lírico respecto de los amantes, por medio del desdoblamiento en tercera persona, por tanto, ofrece: 1) el encubrimiento de toda expresión homoerótica; y 2) el reforzamiento del carácter sublime que sustenta un cierto sentimiento de irrealización del sujeto lírico. Ambas lecturas, pues, parecen aceptables, no independiente una de la otra, sino funcionales simultáneamente; de ahí que su desarrollo abarque las ocho unidades del modelo compositivo lineal de este poema. De acuerdo con López-Casanova (1994), este modelo compositivo comprende una serie variable de unidades, en que se recurren ciertas marcas idénticas de forma paralela (en este caso principalmente la anáfora o paralelismo del susodicho sintagma verbal) y en un mismo nivel de jerarquía.

La luz y las sombras, como afirma Addison (1994), imitan aquellos aspectos naturales que producen en sí sublimidad. Los juegos de desvelamiento (vv. 2-4) y ocultamiento (vv. 8-9) permiten que el lector entrevea dinámicamente, según las sugerencias visuales, el proceso de entrega de la pareja. En este, se reconoce sin dificultad una transición constante desde la noche hasta el día y viceversa, entre una estrofa y otra, o inclusive dentro de una misma como en la cuarta. Esta concentración de luz-oscuridad sublime, por ende, configura una imagen cósmica. Los elementos que demarcan dicha transitoriedad lúdica (casi que onírica) e imagen se encuentran en los versos 2, 5, 10, 14-15 y 22-26.

Este tránsito entre luz y sombras asimismo brinda la sensación de que la pareja se encuentra amando, desentendida del mundo, sin el acecho del tiempo continuo, como si el universo girara dentro de una ucronía alrededor de ellos vislumbrando su amor. En este sentido, la pareja lírica atrae de forma concéntrica la atracción de todos los elementos naturales y circunstanciales que les serían ajenos fuera del momento amatorio. Esta reunión concéntrica estaría marcada estilísticamente por la enumeración caótica de la octava estrofa. Aunque tradicionalmente se ha argumentado que la enumeración caótica consiste en una serie o cadena de términos varios o discordes a fin de reunir lo heterogéneo y construir una visión desintegradora, desarticulada o rota del mundo (Spitzer, 1961; Bousoño, 1985; LópezCasanova, 1994), en este poema dicha figura implica la coincidentia oppositorum, esa reunión de opuestos y lo heterogéneo, pero para afirmar justamente la no-distinción entre el ser y el cosmos, la unidad que estos amantes posibilitan y a la cual pertenecen durante su vivencia homoerótica. Dicha afirmación se ratifica con el sintagma verbal "se querían", a modo de epifonema, en el segundo hemistiquio del alejandrino final. En todo caso, si se quisiera interpretar la enumeración caótica como tradicionalmente se ha pensado, esta vendría a reforzar estilísticamente la identidad y confesiones fragmentadas de un sujeto lírico homosexual; no en vano Losada propone estos tipos de fragmentación como un rasgo de las homotextualizaciones. 
Interrelacionados, pues, los juegos sublimes de luz y sombra, la ucronía y el movimiento concéntrico construyen un centro, símbolo de la intimidad ${ }^{2}$. Este escenario amatorio se configura - valga, por qué no, la tipología de García-Barrientos (2012) para el análisis del espacio en el teatro ${ }^{3}$ - como un plano dramático múltiple, en donde son visibles o patentes dos lugares reales que parecieran, no obstante, ser la mutación de un único espacio, donde los cuerpos homoeróticos negocian y performan su existencia dentro de un marco cósmico que los vuelve visibles y reconocibles, tanto para ellos mismos como para los otros (por ejemplo, los lectores), pues como afirma Torras:

\footnotetext{
El cuerpo es la representación del cuerpo, el cuerpo tiene una existencia performativa dentro de los marcos culturales (con sus códigos) que lo hacen visible. Más que tener un cuerpo o ser un cuerpo, nos convertimos en un cuerpo y lo negociamos, en un proceso entrecruzado con nuestro devenir sujetos, esto es individuos, ciertamente, pero dentro de unas coordenadas que nos hacen identificables, reconocibles, a la vez que nos sujetan a sus determinaciones de ser, estar, parecer o devenir. (2007, p. 20)
}

Como se estaba diciendo, el centro amatorio en este poema parece abarcar dos lugares reales, mutaciones de un único espacio, ya que, cuando se supone es de noche, los amantes líricos habitan un valle (vv. 10-13) y, cuando es de día, ocupan una playa (vv. 18-21). Estos dos espacios - totalmente contrarios y lejanos desde la racionalidad geológica- son reunidos por la fuerza emotiva y subjetiva de lo sublime, la imaginación y la visión, de forma que "valle" y "playa" son dos planos de un mismo sitio, sobre el cual no interesan tanto sus cualidades primarias, sino, en su cualidad de símbolo de la intimidad, el hecho de constituir una posición geográfica donde se experimenta la sensación de ocupar amorosa, erótica y plenamente el centro del cosmos. Este doble plano del centro amatorio se encuentra reforzado por uno de los rasgos poéticos particulares de Aleixandre desde Ámbito: la conjunción "o" con valor identificativo antes que disyuntivo (Bousoño, 1977, 1985; Cano, 1993). Esta "o" homologa, así, a "mar o tierra" en el verso 32. Debido, pues, a este carácter múltiple y cambiante del centro amatorio, se lo metaforiza como "lecho navío" que se mueve no solo entre la "noche" y la "luz", sino también entre los dos planos mencionados ("valle", "playa").

Partiendo de que se trata de dos planos de un único centro, es igualmente significativo observar que el valle y la playa son vivificados por prosopopeyas (vv. 11-12 y 19) e imágenes visionarias (segundo hemistiquio del v. 10-primer hemistiquio del v. 11, segundo hemistiquio del v. 18), las cuales se pueden calificar como surrealistas. El valle y la playa evidencian movilidad y fuerza ctónica ("perros") y acuática (“ondas"), pues ellos son la materialización simbólica de ambos cuerpos amantes. De ahí, por un lado, la asociación incongruente (surrealista) que el símil plantea entre los valles y los lomos, y la metáfora o imagen visionaria continuada que de "lomos" se deriva (v. 13); por otra parte, las metáforas impresionistas (A, b, b') de la playa (vv. 18-19) y los amantes (19-20), así como la reticencia (v. 20) y el epifonema (v. 21) que, conjuntamente, representan la unidad de la luz, el mar, los cuerpos, el cielo y el aire en un espacio cósmico, liminar, abierto y de tensión ("playa"), donde los amantes comportan su homoerotismo, viven su pasión y se exhiben plenos y gozosos, ante la mirada y contemplación de los otros. Uno con el otro y en el otro; ambos uno, sublimes. Así pues, la reticencia indica estilísticamente la elevación que el homoerotismo les permite, y el verso 21 los presenta como sujetos intersticiales ("sobre el mar, bajo el cielo"), o, más bien, como una hierofanía, porque ellos son cuerpos luminosos que comparten el azul marino y celestial y, por tanto, el misterio fascinante de lo cósmico, la inmensidad, lo sublime, su potencialidad de generar éxtasis y transformar al ser en un ente espiritual y físicamente extático ("Mediodía perfecto", "Amando"). 
Desde un punto de vista ecocrítico, podría decirse que esta recurrencia por las uniones cósmicas en la poesía de Aleixandre responde a un deseo del ser humano por olvidar al menos un momento su condición determinada social, religiosa, moral, política, jurídica, educativamente; un deseo de combatir las enajenaciones culturales y, en consecuencia, diluir la dualidad moderna que separa al ser de la naturaleza, para así profundizar en su vínculo con la tierra y olvidar su destino colectivo de separación y aislamiento. Las imágenes visionarias cósmicas de Aleixandre, en este sentido, desarrollarían la metáfora hegeliana del rol ecológico de la poesía: "ubicar al ser humano en la tierra, llevarlo a ella y así vincularlo a la continuidad de la vida cósmica" (Forns-Broggi, 2012, p. 136), debido justamente a esta necesidad de superar la incompetencia e irrealización de los sujetos. De ahí que en las imágenes visionarias de "Se querían" la interconexión dinámica y simbólica entre los dos planos del centro amatorio y los dos amantes evidencie la "función de la tierra": la "reconsideración acerca de lo humano en lo natural. La tierra no es más el mundo externo a nuestros pensamientos, sentimientos y deseos, sino una dimensión clave del universo humano" (Forns-Broggi, 2012, p. 137). Dicha "función de la tierra", reforzada por las fuerzas telúrica, ctónica y acuática en el poema, lleva, por tanto, a profundizar no en la separación trágica de lo humano con lo natural, no en el desarraigo y destrucción modernos del ser humano, sino en su reconstrucción: en la necesidad primigenia, cósmica, plena de "pertenecer a los ciclos de la luz y la sombra, de la vida y la muerte" (Forns-Broggi, 2012, p. 138). El sujeto lírico, pues, lejos de las identidades culturales que sujetan hegemónicamente al ser, parece en este poema ensayar su resacralizar con el cosmos, su reconexión poética, porque la "poesía es el camino más libre y desinteresado para esa imprescindible resacralización" (Forns-Broggi, 2012, p. 136); en consecuencia, se conoce y acepta a sí mismo a través de lo otro: a través del amante, y este a través de aquel, y juntos a través de la naturaleza, su experiencia sublime y directa con ella, su consecuente (con) fusión dinámica y simbólica con ella. Las imágenes visionarias en que los actantes líricos y la naturaleza se (con)funden representan las formas sublimes de resistencia ante la influencia cultural y heteropatriarcal que desea fijar la identidad y comportamientos de los sujetos homosexuales quienes, al materializar fuerzas telúricas, ctónicas, acuáticas y cruzar territorios, se convierten - parafraseando a Forns-Broggi (2012) - en cuerpos liberados de los códigos patrimoniales de la identidad; cuerpos liberados que cruzan nuevos campos de percepción y afectividad de forma abierta y en conexión con la naturaleza.

Habiendo descrito el cronotopos del homoerotismo y esta nueva lectura ecocrítica sobre las redundantes uniones cósmicas en la poesía de Aleixandre, es necesario retomar algunos de los símbolos o recursos anteriores, más otros, para visualizar cómo se realiza parcial o totalmente la entrega erótica de los actantes líricos.

Desde los inicios del encuentro se da preferencia al ambiente nocturno, reforzado por imágenes visionarias ("noche dura", "las duras piedras cerradas de la noche"), prosopopeyas ("luna que llega y toca", "la luna lúcida"), un epíteto metafórico ("mitad noche") y un neologismo nominal ("giralunas"), el cual sigue el paradigma compositivo de "girasol" (López, 1992). A pesar del paralelismo (vv. 3 y 15) y anáfora (vv. 16-17) del adjetivo calificativo especificativo "dura", el simbolismo de la "piedra" - el cual sugiere el carácter hermético, envilecido, profano, estático y sometido al paso del tiempo (Chevalier y Gheerbrant, 1988) - y la relación entre los cuerpos amantes y el frío (símbolo teriomorfo), más que una noche trágica y angustiosa (símbolo nictomorfo), en el poema se construye una noche tranquila (símbolo de la inversión) ${ }^{4}$, eufemizada (vv. 3, 15), de reposo (vv. 16-17), en la cual el homoerotismo se 
plantea, gracias al símil, en términos de una unidad tan natural como la de las flores con las espinas o la de una planta con el sol (vv. 6-7).

Sin embargo, en medio de la oscuridad de donde van surgiendo poco a poco los amantes descritos sinecdóticamente ("labios"), se revelan dos símbolos llamativos. Por un lado, la "sangre" (v. 4) podría interpretarse en un primer momento como un símbolo nictomorfo, dado que connotaría lo impuro y lo prohibido, así como un símbolo catamorfo ${ }^{5}$, pues dicha impureza y prohibición, asociadas con lo sexual, establecerían un isomorfismo donde la sangre se vincularía a la caída moral, cuyo esquema simbólico no es más que el tema del tiempo nefasto (Durand, 1982). En otras palabras, esta sangre recordaría al sujeto lírico que la relación homoerótica que está desdoblando o sublimando es pecaminosa, mortal y, por tanto, moralizada en forma de castigo; de ahí la recurrencia inmediata a la reduplicación del símbolo y la interrogación (v. 4), pregunta que plantea la preocupación del sujeto lírico en torno a la relación homoerótica y una posible sanción penal, médica, ética, social, política o religiosa como las instauradas por los discursos decimonónicos con respecto a los homosexuales (Dyer, 1993; Mira, 2004; Campos, 2016). No obstante, el verso 5 parece responder a esta interrogante y eufemizar todo simbolismo negativo de la sangre, por lo que, en un segundo momento, esta puede interpretarse como símbolo de la inversión y, por ende, sinécdoque de los amantes y su pasión, ya que la sangre representa el calor vital, corporal y espiritual, la energía pasional (Chevalier y Gheerbrant, 1988).

A pesar de esta segunda connotación, sin duda presente también en el poema, en la siguiente estrofa aparece el otro símbolo llamativo, relacionado más bien con el simbolismo nictomorfo y catamorfo de la "sangre": la melancolía. Durante la primera mitad del siglo $\mathrm{XX}$, tanto el temor a la injuria como la armarización física y psicológica seguían generando timidez, tristeza y melancolía. Estas dos últimas eran síntomas homosexuales según la medicina decimonónica (Tardieu, 1863; Peratoner, 1892). El verso 8 evidencia cómo la "melancolía”, es decir, el miedo a estar cometiendo un acto criminal, desviadamente patológico, moralmente degenerado y nefando, está presente en los actantes líricos de este poema. Sin embargo, en el "rostro" de ellos no solo se observa dicha "melancolía", sino también el brillo que les da el goce de la unión espiritual y corporal a través del "beso" (Chevalier y Gheerbrant, 1988), pues la fuerza, intensidad y frotamiento (vv. 9 y 17) que conlleva este símbolo del progreso connota el movimiento rítmico, agradable y productivo de la sexualidad ${ }^{6}$.

Esta doble lectura simultánea de la "sangre" y de la coincidentia oppositorum "melancolía" / "beso" permite, en consecuencia, interpretar también doblemente el sintagma verbal: "Sufrían por la luz". Por una parte, este sintagma verbal, aunado a aquel carácter hermético, secreto y frío de la oscuridad nocturna, sugeriría que los amantes se encuentran escondidos, aislados, viviendo su pasión y, por consiguiente, temerosos de ser víctimas de su propia entrega. Si se les suman a aquel sintagma y aquellos valores de la "noche" las connotaciones de la "melancolía" y la acción evasiva de los "rostros" del verso 8, se conseguiría leer que, en efecto, la pareja sufre de un aislamiento, producto de su temor a la injuria, al habitus homofóbicos; en este sentido, la "luz" funcionaría como un símbolo espectacular", pues representaría, justamente, el poder del discurso hegemónico heteronormativo que vendría a vencer la "noche", sancionar y sanar la "sangre" homosexual. Los actantes líricos, por consiguiente, preferirían ocultarse, distanciarse de cuanto los afecte, les haga temer la "sangre", el castigo de su caída moral.

"Sufrían por la luz", no obstante, se puede leer complementariamente de otra manera dentro de la ambivalencia que los símbolos e imágenes ofrecen. Frente a esa "noche dura", 
"sangre" negativa y "melancolía", la pasión de los amantes, su "luz" (esta actuaría ahora como un símbolo del progreso), aunada al "beso", permitirían leer que el sufrimiento de los amantes no es sino el goce intenso y consumación del acto sexual. La pareja se compenetraría, pues, indiferente al mundo y las circunstancias que la amenacen, como podría sugerir el verso 5 al responder a la interrogación del verso 4; o bien la personificación de los "valles" y la "playa" como extensiones de la pareja, justamente, en su unión con lo cósmico, pues la amplitud del espacio ("horizontes remotos"), evidenciarían la "intimidad extensa", el sufrimiento luminoso de aquella.

Como consecuencia de este ocultamiento-goce, en la sexta estrofa se representa el clímax de esta unión erótico-cósmica. El dinamismo expresivo negativo (López-Casanova, 1994) ha venido generando un movimiento lento, detenido, retardatorio que permite describir y contemplar mejor la entrega de los amantes y su vivencia plena del amor. Llegado a este punto, el cenit ("mediodía perfecto") aparece como un isomorfismo espectacular y ascensional", pues connota, primero, la luminosidad de la unión y, segundo, la elevación de los cuerpos en su furor sexual ("los peces rojos van y vienen sin música"), en medio de la amplitud del espacio telúrico y marino. Asimismo, el "mar" aparece como símbolo de la intimidad por ser morada o resguardo, en cuanto es uno de los dos planos del centro amatorio. Este triple isomorfismo de símbolos espectaculares, ascensionales y de la intimidad eufemiza a la "soledad", la cual no aparecería como un símbolo catamorfo, sino como otro símbolo de la intimidad que, a su vez, establece, en el verso 25, otro isomorfismo con el canto (símbolo del progreso): la rítmica musical-erótica del acto sexual.

La estrofa séptima vendría a marcar el anticlímax del poema. En ella, los amantes aparecen en reposo, "amando"; de ahí que se recurra de nuevo, dentro de la ucronía sublime, a la "noche" tranquila ("luna lúcida"), a la expresión doblemente oscura de los rostros amantes ("mejilla oscurecida") y los símbolos de la intimidad expuestos ("mar redondo"). Obsérvese cómo, ligado a este último símbolo, la experiencia sublime de la visión permite la producción de la sinestesia "dulce eclipse del agua". Mientras que en toda visión se combinan lo afectivo y la irracionalidad, en la sinestesia se intercambian o mezclan las sensaciones y sentimientos; en ambos recursos siempre median las sensaciones internas, de ahí que se pueda decir que la vivencia de lo sublime y la génesis de sinestesias se encuentren relacionadas analógicamente.

La línea de tensión climática se cierra con la enumeración caótica. Como se ha dicho, esta puede leerse asimismo en dos direcciones: movimiento concéntrico que lleva a la reunión de lo heterogéneo con los amantes en el centro amatorio, o identidad y confesión fragmentadas de lo homoerótico. En ambos sentidos, no obstante, esta enumeración plantea un desenlace particular, ya que corresponde a un acercamiento sublime donde intervienen la imaginación y la liberación de las imágenes en conjunto, por medio de la acumulación de elementos sinecdóticos de la pareja o las circunstancias y objetos periféricos, sin perder relación con los valores indiciales y niveles de sugerencia de la entrega amorosa; es decir, la transición temporespacial representada con el juego sublime de luz-sombra, el ritmo del encuentro a partir del movimiento concéntrico reflejado en el "agua" (“ondas"), el desplazamiento de los cuerpos que coincide con el de las visiones sublimes respecto de un espacio firme y pasivo ("tierra") hasta el cambiante y activo ("mar"), un ambiente que es todo fuerza ("lecho"), suavidad ("pluma”), calma ("cristal”, "metal”), armonía ("música”, "silencio"), ascensión y transformación ("vegetal"); y, al final, liberación homoerótica íntima y cósmica ("mundo, quietud, su forma. Se querían, sabedlo"). Esta asociación de símbolos uno tras otro representa una consecuencia misma de la continuidad imaginativa de los valores sublimes de la entrega 
pasional inmutable, atemporal y trascendental. Según Bousoño (1985), una gradación consiste en una enumeración escalonada de términos que coinciden en marcar una misma dirección hacia el punto expresado por el último elemento de la serie. Si se considera este final como una gradación, todo el sentido iría encaminado hacia el verbo ("sabedlo"). Este llama al reconocimiento de la entrega homoerótica que late, se oscurece, resplandece y sufre una transformación a lo largo de todo el poema, impulsándose desde una perspectiva de unión y pertenencia también con el universo, y su esencia de unión natural opuesta a todos aquellos discursos hegemónicos que pregonan la contranaturaleza de la homosexualidad. En otras palabras, con esta gradación el sujeto lírico sugiere que la unión homoerótica es una expresión de amor otro, mediante la cual se da igualmente la vivencia de unidad erótico-cósmica.

En fin, este poema, como se demuestra, es el desarrollo de una imagen que se extiende desde el principio hasta el final gracias al modelo compositivo lineal. Dicha imagen se reitera de forma anafórica, con el fin de fortalecer la aproximación al acto sublime y todos sus puntos cumbres, oscurecidos, no por prohibidos, sino por causar una mayor atracción de la imaginación y de las sensaciones internas. No resulta arbitraria, entonces, la anáfora del sintagma "se querían", la cual sostiene la estructura sublime a lo largo del texto, mientras que los otros verbos aparecen subordinados o perifrásticos para contribuir con esa sensación de giro cósmico alrededor de la pareja. La anáfora en cuanto figura de dicción por repetición aparece como la respuesta sintáctica a un mundo bullidor, abundante, apasionado, quieto. No importa a cuál sensación conduzca: la utilización de la anáfora se dirige a traducir los esfuerzos reveladores de un mundo que deja de ser objetivo para convertirse en esencia imaginativa $u$ onírica. De ahí que la anáfora ejerza en el lector cierta tensión de sublimidad y fascinación.

Toda esta única imagen-poema parece concordar con un sueño, debido al ludismo planteado en relación con el giro en torno a los amantes, los planos del centro amatorio y la alternancia de los elementos naturales, circunstanciales y la intensidad que poseen la evolución lírica, de modo que el lector al final pareciera haber presenciado y vivido igualmente un viaje onírico, rasgo poético que también ha de identificarse en la primera estrofa del siguiente poema. Esta construcción lúdico-onírica se consigue no solo a través del juego sublime entre la luz y la sombra, sino aun a la experiencia sublime vivida ante lo macrocósmico - desde lo celestial ("madrugada", "noche", "amorosa gema del amarillo nuevo", "luna", "mediodía", “día", "ponientes"), telúrico ("lecho navío", "valles", "lomos arcaicos", "horizontes remotos", "espacios", "mundo"), ctónico ("los perros hondos/ laten bajo la tierra") hasta lo marítimo ("mar", "ondas nuevas, antiguas, fugitivas, perpetuas") - como ante lo microcósmico ("sangre", "flores", "espinas", "caricia, seda, mano", "diente", "rostro", "mejilla", "pluma, cristal,/ metal, música, labio, silencio, vegetal", "quietud").

\section{2 "Mano entregada"}

Pero otro día toco tu mano. Mano tibia. Tu delicada mano silente. A veces cierro mis ojos y toco leve tu mano, leve toque que comprueba su forma, que tienta su estructura, sintiendo bajo

la piel alada el duro hueso 


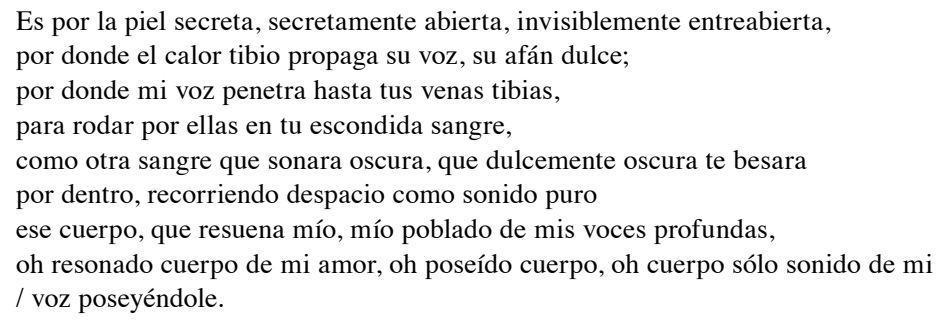

Por eso, cuando acaricio tu mano, sé que sólo el hueso rehúsa mi amor -el nunca incandescente hueso del hombre.

Y que una zona triste de tu ser se rehúsa,

mientras tu carne entera llega un instante lúcido

en que total flamea, por virtud de ese lento contacto de tu mano,

de tu porosa mano suavísima que gime,

tu delicada mano silente, por donde entro

despacio, despacísimo, secretamente en tu vida,

hasta tus venas hondas totales donde bogo,

donde te pueblo y canto completo entre tu carne. (Aleixandre, 1976, pp. 197-198)

A diferencia del anterior, la retórica de este poema dosifica y conserva los niveles sublimes mediante un lenguaje más sencillo, que da paso al versolibrismo y el versículo. La sencillez de este lenguaje ilustra cómo lo sublime puede llegar a ser expresado con simplicidad (Addison, 1994), a pesar de la explicativa redundancia e intensa repetición que es el texto mismo (Pihler, 2013), en el desarrollo de una sola imagen, como sucede en el poema anterior. En esta ocasión, el desarrollo de esta imagen medular se logra mediante un modelo compositivo analítico 9 : el verso 1 se presenta como la base-afirmación, donde se presentan metonímicamente al otro ("mano") y el deseo del sujeto lírico por tocarlo; de modo que las dos estrofas restantes constituirían las unidades explicativas de este deseo.

El dinamismo expresivo negativo de las recurrencias en este poema se establece por medio de la hipotaxis, la cual ralentiza el ritmo de lectura (Bousoño, 1985; López-Casanova, 1994). Contribuyen asimismo a este ritmo lento, primero, la combinación de verbos en tiempo presente actualizador con valor histórico, habitual y generalizador: "otro día toco", "a veces cierro"; y, segundo, las políptoton o derivaciones: "toco leve tu mano, leve toque", "Es por la piel secreta, secretamente abierta, invisiblemente entreabierta", "ese cuerpo, que resuena mío, [...] oh resonado cuerpo de mi amor", "su afán dulce [...] que dulcemente oscura te besara", "oh poseído cuerpo, oh cuerpo sólo sonido de mi voz poseyéndole", "despacio, despacísimo" (Pihler, 2013). Habría que agregar a estas figuras la repetición diseminada de "mano", "hueso", "piel", "sangre", "tibio", "cuerpo"; reduplicaciones ("mano", "mío"), reiteraciones ("leve", "que”, "oscura", “oh", “cuerpo"), anáforas ("por donde"), anadiplosis ("tu escondida sangre, como otra sangre") y una epífora ("rehúsa").

Como lo indica el título de tipo factual (López-Casanova, 1994), la "mano" es el símbolo medular del poema. Esta "mano" es sinécdoque de un tú lírico al que podría identificarse como masculino, a pesar de que el sujeto lírico emplee el recurso homotextual del enmascaramiento, usando adjetivos calificativos especificativos ("tibia", "delicada", "silente", "leve", "dulce"), que tradicionalmente han sido utilizados para describir figuras femeninas. La delicada y sutil prosopografía de esta "mano" en realidad es ambigua y permite visualizar, bajo aquellos aparentes rasgos femeninos, una "mano" masculina latente que, poco a poco, dentro de la misma primera estrofa, desvela su naturaleza varonil. ¿De qué manera? Los rasgos femeninos 
de esta "mano" permitirían pensar que se está representando al tú lírico — según se empezó a decir a finales del siglo XIX - como un sujeto uranista: un hombre con psique femenina (Kaylor, 2006), quien, por ende, comportaría cierta timidez, inocencia y reflejaría cierta imagen de mujer. La única posibilidad de contactar con este sujeto masculino es por medio de la sublimación: cerrando los "ojos" y ensoñando el "leve toque". Obsérvese que, pese a la femenina descripción, se retrata a la "mano" del amado como "el duro hueso/ insobornable, el triste hueso adonde no llega nunca el amor". Los discursos decimonónicos asociaron la tristeza con los sujetos uranistas y, como se ha dicho anteriormente, también con la "melancolía", pues ambas eran consideradas síntomas de la homosexualidad.

En la primera estrofa, pues, lo sublime se focaliza en visiones y sensaciones táctiles sobre la "mano" del amado. Los verbos "cierro" y "toco" remiten a las sensaciones secundarias que la imaginación permite recoger del objeto observado; por eso, tales acciones posibilitan al sujeto lírico sentir la textura, "forma", "estructura", dureza, calor y movimientos de la otra "mano". No es de extrañar, en este sentido, que la subordinación sintáctica de largos períodos mantenga un tono descriptivo, e inclusive se utilice el apóstrofe (v. 7) para establecer el contacto sinecdótico y subliminal con el tú lírico. Así pues, los niveles afectivos de la visión resaltan antes que los juegos retóricos o imágenes visionarias, por ejemplo, de "Se querían".

En la segunda estrofa, se continúa la imagen distante del amado, retratándolo ahora como "piel secreta, secretamente abierta, invisiblemente entreabierta". El juego con el políptoton y los adverbios en este último verso citado sugiere el ocultamiento-desvelamiento de la naturaleza uranista de la "mano". Esta imagen, por tanto, permite la reunión de los contrarios.

Los versos 11-12 retoman el juego sublime de la luz y las sombras, de modo que se oscurece, se esconde no solo la "mano" del amado, sino su brazo, su cuerpo, su silueta; se la enmascara de nuevo; se la ve como una "sangre" en la que el sujeto lírico resuena mediante su palabra y, a su vez, es tocado por dicha "sangre [...] que dulcemente oscura te besara/ por dentro". A través no solo de su visión y sensación táctil, sino también del sonido de su "voz", como dijera Minkowski (1999), el sujeto lírico resuena en el otro, toca al otro, al mismo tiempo que el otro resuena en aquel y lo toca. Aunque no haya contacto directo, quizás por temor a la mostración pública y sufrir la injuria o la caída moralizadora de la "sangre" (símbolo nictomorfo), los cuerpos amantes sí se tocan, sí se unen fenomenológica e imaginariamente, gracias a la visión sublime, las cualidades afectivas del tacto y la resonancia de la voz misma que es el poema. Así los cuerpos homosexuales trascienden la reclusión, el escondite secreto, la distancia, el temor o la prohibición y se convierten en "sonido puro", unidad consigo mismos y el cosmos, cuerpos sublimemente poseyéndose y poseídos (vv. 14-15). De ahí que, como al final de la primera, se retome en esta estrofa el apóstrofe, con el fin de aseverar y exaltar lo sublime del homoerotismo. Nótese, además, cómo, principalmente en esta segunda estrofa al igual que en "Se querían", la vivencia de lo sublime motiva la generación de sinestesias: "afán dulce", "que sonara oscura, que dulcemente oscura te besara".

En la última estrofa, por un lado, el epíteto-frase del verso 17 reafirmaría que, en efecto, se trata de una "mano" de "hombre", si se lee este último no como sustantivo con género común, sino con género exclusivamente masculino. Por otro lado, la epífora del "rehúsa" enfatiza el rechazo que el tú lírico tendría de la mano del sujeto lírico sobre la suya en un contacto directo público, vedado. Sin embargo, opuesto a este contacto, se acepta y ratifica el tacto sublime homoerótico, en ese "instante lúcido" cuando, de nuevo, la visión traduce todas las afecciones amorosas y unitivas de estos dos sujetos homosexuales (vv. 19-25), inclusive con cierto ternurismo que el políptoton de "despacio", el adverbio "secretamente" y las dos 
oraciones subordinadas adjetivas referidas a "venas" inscriben. Esto evidenciaría, como dice Pérez, que: "La carne entera arde en llamaradas por el contacto de la mano, que dulcísima gime en silencio y por donde el amado se puebla del amante, que navega jubiloso por las hondas venas del ser amado" (2001, p. 284).

En fin, obsérvese que en este poema predomina una carga subliminal sostenida por: 1) un lenguaje sencillo, aunque explicativo y de dinamismo lento; 2) un acercamiento a lo sublime por medio de lo microcósmico, marcado principalmente por la metonimia ("mano", "sangre", "piel", "hueso", "carne", "calor", "voz", “venas", "sonido"); 3) un enmascaramiento adjetival y descriptivo ambiguo del amado; 4) el juego entre la luz y las sombras; 5) la recurrencia a la visión que asimila las cualidades emotivo-afectivas de las sensaciones táctiles y aun las fenomenológicas de la resonancia del sujeto lírico en el cuerpo del otro y viceversa; 6) la sinestesia; 7) una distancia física que aviva su tacto subliminal, sus deseos unitivos de ser "manos entregadas", al mismo tiempo que les recuerda su tristeza, ambigüiedad, invisibilidad, temor, reclusión y silenciamiento.

\section{3 "No busques, no"}

Yo te he querido como nunca.

Eras azul como noche que acaba,

eras la impenetrable caparazón del galápago

que se oculta bajo la roca de la amorosa llegada de la luz.

Eras la sombra torpe

que cuaja entre los dedos cuando en tierra dormimos solitarios.

De nada serviría besar tu oscura encrucijada de sangre alterna,

donde de pronto el pulso navegaba

y de pronto faltaba como un mar que desprecia a la arena.

La sequedad viviente de unos ojos marchitos,

de los que yo veía a través de las lágrimas,

era una caricia para herir las pupilas,

sin que siquiera el párpado se cerrase en defensa.

Cuán amorosa forma

la del suelo las noches del verano

cuando echado en la tierra se acaricia este mundo que rueda,

la sequedad oscura,

la sordera profunda,

la cerrazón a todo,

que transcurre como lo más ajeno a un sollozo.

Tú, pobre hombre que duermes

sin notar esa luna trunca

que gemebunda apenas si te roza;

tú, que viajas postrero

con la corteza seca que rueda entre tus brazos,

no beses el silencio sin falla por donde nunca

a la sangre se espía,

por donde será inútil la busca del calor

que por los labios se bebe

y hace fulgir el cuerpo como con una luz azul si la noche es de plomo.

No, no busques esa gota pequeñita,

ese mundo reducido o sangre mínima,

esa lágrima que ha latido

y en la que apoyar la mejilla descansa. (Aleixandre, 1993, pp. 120-121) 
Desde el título de tipo factual (López-Casanova, 1994), en este poema se plantea la (no) búsqueda del amado. Puede leerse simultáneamente una búsqueda o una no-búsqueda de este, ya que el uso de la negación - rasgo poético particular de Aleixandre desde Espadas como labios - ofrece un triple valor: 1) la negación de lo real, 2) la negación de lo irreal y 3) la negación cuasi-afirmativa (Bousoño, 1977, 1985; Cano, 1993). Dicho uso se sustenta, ergo, en la potencialidad de la lítote y la antífrasis. Considerando estos tres valores, podría decirse que desde el título mismo el sujeto lírico: 1) le pide al tú lírico que se aparte; 2) le pide que supere las circunstancias o factores hipotéticos que les impiden acercarse y, por tanto, suponen su distancia, separación ("lágrima”); 3) realmente lo está llamando a esa búsqueda, ese encuentro, que detendrá esa "lágrima" que en el rostro de ambos aparece. Las tres lecturas, como se verá, son posibles.

El sujeto lírico confiesa su amor al tú lírico en el verso 1 y entre los versos 2-6 lo describe. Igual que en los dos poemas anteriores, se recurre al juego sublime de luces y sombras, con el fin de difuminar la figura de este tú (v. 2); acentuar metafóricamente su ocultamiento, y sus caracteres hermético, indiferente, esquivo, casi inconmovible, nocturno (vv. 3-4); así como enfatizar, por medio de la sinécdoque y sinestesia fusionadas ("sombra torpe/ que cuaja entre los dedos"), el apartamiento, la reclusión, el secreto, la soledad, es decir la armarización -la apartada "tierra" electa por los actantes líricos vendría a ser una sublimación del clóset- que a los amantes homosexuales parece quedarles, ante el espacio público y la censura.

En la segunda estrofa, la contemplación permite al sujeto lírico continuar el retrato oscuramente sublime del tú lírico gracias a la imagen visionaria (vv. 7-9) y la visión (vv. 10-13). Aparece, como refuerzo de este carácter hermético, distante e inexpresivo del tú lírico, la "sequedad", símbolo teriomorfo que evoca, desde el discurso bíblico, el sufrimiento y la esterilidad interior (Chevalier y Gheerbrant, 1988). Dicha "sequedad" es sinécdoque de la psique del tú lírico, así como de la noche de "verano", la dimensión temporal del poema. Ante esta "sequedad" del amado y el ambiente, pues, "De nada serviría besar": de nada serviría el unirse al menos por un instante, o al menos parece difícil el unirse al otro siquiera un momento, salvo mediante la visión sublime. De ahí que esta, aunada a la exclamación, la metonimia ("forma"), la anáfora ("la") y la sinestesia ("la sequedad oscura"), termine de construir enfática y emotivamente el retrato del amado y el cronotopo del poema ("tierra", "suelo" + "noche", "verano").

Obsérvese que en los versos 14-16 se plantea la unificación de los cuerpos amantes con el cosmos gracias a su reposar secreto sobre el suelo veraniego; así, este cronotopo trazaría un centro amatorio (símbolo de la intimidad), a pesar de la armarización sugerida. En este sentido, la "sordera profunda" podría connotar, primero, silenciamiento que los sujetos homosexuales comportarían durante su armarización; segundo, el carácter hermético del tú lírico; tercero, la tranquilidad y confidencia de ocupar dicho centro. En todo caso, el símbolo que cierra la estrofa ("sollozo") se relaciona con las "lágrimas" susodichas. Estas constituirían un símbolo nictomorfo, al representar el sufrimiento y el paso del tiempo que separa a los amantes (v. 20).

Hasta aquí se poetiza la negación de lo irreal, sugerida desde el título. ¡Qué más irreal que un sujeto homosexual pues, como afirma Rojas (2012), está relegado a la irrealidad (la inexistencia e irrealización) dentro del ámbito real: el orden (hetero)patriarcal! Con el uso anafórico del apóstrofe en los primeros cinco versos de la cuarta estrofa, el sujeto lírico reactualiza y apela a la indiferencia y "sequedad" del tú lírico, a pesar de que ahora se presenta, en medio del devenir temporal - marcado por la "luna" y la aliteración de los fonemas /e/ y /a/ en el v. 25-, a ambos actantes más unidos: el sujeto lírico parece descansar, 
anímicamente cambiante, entre los "brazos" del otro; así lo sugieren las imágenes visionarias de los versos 22-23 y 25. Acto seguido, el uso de la negación permite leer los otros dos valores aleixandrinos del adverbio: la negación de lo real de su homoerotismo y la cuasi-afirmación de este a través del imperativo de "besar". Esta negación-afirmación implica desconocerespiar, repeler-aceptar el centro amatorio ("silencio", "noche”, "plomo") y el "cuerpo" del otro ("sangre", "calor", "labios", "luz azul").

Obsérvese que el uso del sustantivo "hombre" en el verso 21 permitiría ratificar el género masculino del tú lírico. No obstante, ¿qué pasaría si se tratara de un desdoblamiento de primer grado (López-Casanova, 1994), en el cual el sujeto lírico se esté dirigiendo a sí mismo mediante el tú de la reflexión? En este caso, todo este juego de negación-afirmación evidenciaría la (im)posibilidad del sujeto lírico por reconocer y aceptar privada y públicamente su "beso", su deseo, su homoerotismo.

Esta (im)posibilidad del "beso", por tanto, se reafirma en el clímax del poema: la quinta estrofa. Esta base-afirmación evidencia, por una parte, el modelo compositivo sintético del texto ${ }^{10}$; por otra, el deseo del amado de (no) buscar al sujeto lírico, si se asume que el tú es otro individuo, o bien el deseo del sujeto lírico de (no) buscarse y, por tanto, al amado, si se asume que se trate de un desdoblamiento. En ambos casos el otro, ya sea el amado, ya sea el mismo sujeto lírico, estaría retratado por medio de tres sinécdoques (vv. 31-33), cuyos núcleos nominales sintetizan los simbolismos negativos (isomorfismo nictomorfo y catamorfo) y positivo de la "sangre" por un lado; y, por otro, el simbolismo nictomorfo de la "lágrima", aunque también uno positivo, puesto que el hipérbaton del último verso agrega a la "lágrima" un valor de goce y reposo, resultante de la posibilidad del "beso". Obsérvese que en esta última estrofa se emplea de nuevo la "o" aleixandrina para unificar esos símbolos que representan en sí al otro, como parte de una vivencia sublime que, marcada mediante los epítetos enfáticos, expresa la fascinación por lo microcósmico: esa gota pequeñita,/ ese mundo reducido o sangre mínima.

En fin, la estructura de este tercer poema se encuentra sostenida por la interacción de figuras estilísticas, visiones y símbolos que desarrollan una sola imagen —no onírica como en "Se querían", ni ternurista como en "Mano entregada"-, sino más bien patética, donde el sujeto lírico recurre a la lítote y la antífrasis para implorar, con un tono disfórico, a su amado o a sí mismo la negación-aceptación de su deseo homoerótico.

\section{Lo sublime en la homopoética aleixandrina}

Como se ha demostrado en el análisis de "Se querían", "Mano entregada" y "No busques, no", lo sublime, en efecto, participa significativamente en la consolidación de la homopoética aleixandrina definiendo, como recursos de homotextualización:

1. El juego de luces y sombras que implicaría, consecuentemente, las estrategias de ocultamiento-desvelamiento de los sujetos homosexuales y la negación-afirmación de su deseo homoerótico, en medio de un espacio conflictivo que se esboza con tensión entre el ámbito público y el privado, la injuria y la vivencia íntima plena.

2. La ambigüedad proporcionada por el símbolo, la metáfora, las imágenes visionarias y las descripciones ya que, bajo su carga semántica e imaginativa, se manifiesta de forma latente el género y rasgos masculinos de los actantes líricos.

3. El hermetismo, asociado con lo nocturno, la silueta de los amantes, el espacio y el contacto físico y erótico-amoroso, aparece como consecuencia de una apertura parcial 
de lo irracional, lo reprimido, lo silenciado, lo invisibilizado, lo armarizado, debido a la necesidad de expresar la plenitud que paradójicamente genera la incompletud del ser.

4. El desdoblamiento como mecanismo para enmascarar los deseos del yo o el otro, distanciarse con respecto a expresiones pasionales homoeróticas, o sublimar la irrealización personal del homoerotismo.

5. Los límites de lo macrocósmico y lo microcósmico como extremos de lo sublime, dentro de los cuales se plantean las visiones de separación de los amantes, reforzadas por símbolos nictomorfos ("noche", "sangre", "lágrimas") y teriomorfos (frío, "sequedad"); o bien su unión carnal-espiritual y cósmica, reforzadas por símbolos de la intimidad (centro, "mar", "soledad"), de la inversión ("noche”), del progreso ("beso", canto) o espectaculares ("luz", cenit).

6. La recurrencia al símbolo de la "sangre", cuya ambivalencia permite leer, por un lado, el isomorfismo nictomorfo-catamorfo, según aquella refiere a la muerte, negación, destrucción y castigo moral a que se ven expuestos los sujetos homosexuales por el habitus homofóbico y los discursos hegemónicos heteronormativos; por otra parte, el simbolismo de la inversión, según el cual la "sangre" connotaría el calor de la vida, los cuerpos y espíritus de los amantes; la energía pasional plena e íntegra de su manifestación en un tiempo y un espacio. La "sangre" en cuanto símbolo redundante en la homopoética aleixandrina presenta las dos caras de todo acto vital, humano y, por tanto, poético.

7. Las imágenes visionarias que, aunque novedosas, oníricas, unitivas y cósmicas, no plantean una rebelión suscitada por la misma expresión irracional del surrealismo contra la identidad y la sexualidad heteronormativas, como sí ocurrió, por ejemplo, en las imágenes visionarias surrealistas de Un río, un amor o Los placeres prohibidos, en las que, como ha dicho Octavio Paz, Cernuda "comprendió e hizo suya la verdadera significación del surrealismo como movimiento de liberación — no del verso sino de la conciencia" (1964, citado en Harris, 2005, p. 37).

8. Las visiones tanto fenomenológicas (visual, e inclusive táctil o sonoro) como imaginativas para traducir las cargas afectivas, sensitivas, libidinosas, espirituales y existenciales que los sujetos homosexuales tienen vedadas o temen comportar ante el habitus homofóbico.

9. Una conciencia ecológica que busca trascender la dualidad moderna entre ser humano y naturaleza, con el propósito de superar y resistir las enajenaciones culturales que separan al ser humano del cosmos, fijan la (heterono)normatividad de la identidad y los comportamientos y conducen al ser hacia su incompetencia e irrealización; a la inexistencia, en el caso de los sujetos homosexuales. De ahí que dicha conciencia ecológica se manifieste a través de las imágenes visionarias y la experiencia sublime de la luz-sombra, a fin de profundizar en el vínculo del ser humano con la tierra, olvidar su destino colectivo de separación y aislamiento y reconstruir, gracias a la "función de la tierra", en la medida de lo posible su propio reconocimiento, aceptación en lo otro y con ello, y (re)convertirse en cuerpos cósmicos liberados.

10. La generación de sinestesias, como resultado de la combinación de las afecciones, lo irracional y las sensaciones internas que materializan igualmente las vivencias sublimes.

11. La fragmentación de la identidad y confesiones homoeróticas, marcada enfática y exclusivamente por tropos como la metonimia y la sinécdoque. 
12. La antífrasis y la lítote como estratos del lenguaje negativo frecuente en la poesía aleixandrina, con el fin de dejar en el nivel de lo entredicho, indeterminado y ambiguo la clara afirmación de las realidades, circunstancias, deseos y actantes homoeróticos.

Lo sublime en la homopoética aleixandrina, pues, se manifiesta como ese intento por transformar siempre los elementos y vivencias cotidianas en un algo que eleva y transforma al sujeto lírico; ese intento por captar la esencia de las experiencias homoeróticas por medio de la imaginación. Su expresión es transmitida por una retórica más compleja en el primero y último poemas, mientras que en "Mano entregada" se emplea un lenguaje más sencillo. En este sentido, el profuso empleo de figuras de dicción por adición de palabras (epítetos), repetición de palabras (anáforas, epíforas, reduplicaciones, repetición diseminada o anadiplosis) o analogía de accidentes gramaticales (políptoton), figuras de pensamiento descriptivas (prosopografía, retrato), patéticas (interrogación, exclamación, apóstrofe) o intencionales (antífrasis, lítote), o bien tropos como metáforas, símiles o prosopopeyas, viene a cumplir su función retórica acorde con el contexto en que estos textos fueron compuestos: enunciar, desarrollar, aproximar y ocultar al lector las vivencias sensoriales, imaginativas y sensuales de unos cuerpos perseguidos que, en su deseo de representarse como cuerpos liberados, no tuvieron sino esta forma de decirse ante la imposibilidad de desvelar su homoerotismo, la expresión más verdadera de su amor humano.

\section{Notas}

1. Fernández (2016) reproduce dos cartas y un poema inédito que Aleixandre dirigió a Carlos Bousoño, los cuales Calderón (2003) recoge en su estudio biográfico.

2. Los símbolos de la intimidad del régimen nocturno agrupan todos aquellos relacionados con los continentes y los contenidos, las imágenes de la interioridad y el reposo, debido al gesto del acurrucamiento y el reflejo digestivo (Durand, 1982).

3. Como dice García-Barrientos (2012), mientras la narrativa tiende a representar un mundo lleno, abigarrado, y procede a la acumulación de datos sobre el mundo ficticio, el drama procede al vaciado del mundo, para marcar sus líneas de fuerza, estilizar y configurar un arte de despojamiento, de reducción a lo esencial; en otras palabras, lo pertinente en el drama desarticula los "efectos de realidad" característicos del relato, ya que el primero no necesita de artificios de realidad, pues tiende al empleo de efectos antiilusionistas o distanciadores, contrarios a los efectos ilusionistas en el relato. ¿Acaso no comparten la poesía y el drama este mismo proceder al vaciado y los mismos efectos antiilisuionistas o distanciadores de la realidad?

4. Dentro del régimen diurno de lo imaginario, se ubican, por un lado, los símbolos teriomorfos, los cuales se refieren a la monstruosidad animal, las inclemencias y catástrofes meteorológicas, el movimiento fugaz, cambiante, doloroso y caótico del tiempo; y, por otra parte, los símbolos nictomorfos, asociados al ámbito de las tinieblas y la oscuridad. Por su lado, los símbolos de la inversión pertenecen al régimen nocturno y buscan eufemizar todos los valores del régimen diurno a través del esquema del descenso (Durand, 1982).

5. Los símbolos catamorfos son el tercer tipo de los presentes en la parte negativa del régimen diurno; remiten a la caída, el abismo y la carne (Durand, 1982).

6. Los símbolos del progreso se sitúan dentro del régimen cíclico o copulativo; pertenecen a un esquema rítmico asociado con el reflejo o dominante sexual, que permite agrupar todos aquellos símbolos relativos a los utensilios humanos y el símbolo del árbol, que connotan el avance del ser humano a medida que acepta lo positivo del tiempo e incide en el progreso (Durand, 1982).

7. Los símbolos espectaculares se asocian con la luz, lo solar, la videncia y la palabra (Durand, 1982).

8. Los símbolos ascensionales son aquellos relacionados con la posición erguida, la sublimidad, la verticalidad espiritual, la ascensión y la soberanía (militar, jurídica, religiosa). 
9. De acuerdo con López-Casanova (1994), este modelo presenta una base-afirmación al inicio del texto y, a raíz de ella, una serie de unidades explicativas de tal aserto.

10. Un modelo compositivo sintético se articula cuando se parte de unidades explicativas y de carácter condensador hacia una base-afirmación ubicada al final del texto, según López-Casanova (1994).

\section{Bibliografía}

Addison, J. (1994). Los placeres de la imaginación y otros ensayos de The Spectador. Madrid: Visor.

Aleixandre, V. (1976). Mis mejores poemas. Madrid: Gredos.

Aleixandre, V. (1993). Espadas como labios; La destrucción o el amor. Madrid: Castalia.

Bousoño, C. (1977). La poesía de Vicente Aleixandre. Madrid: Gredos.

Bousoño, C. (1985). Teoría de la expresión poética. Madrid: Gredos.

Calderón, E. (2016). Vicente Aleixandre. La memoria de un hombre está en sus besos. Barcelona: Stella Maris.

Campos, R. (2016). Identidad y homosexualidad en la poesía cubana. La diversidad en la literatura, el cine y la prensa española contemporánea. (455-464). Santiago de Compostela: Andavira.

Cano, J. (1993). Introducción biográfica y crítica. Por V. Aleixandre. Espadas como labios; La destrucción o el amor. (9-32). Madrid: Castalia.

Chevalier, J. y Gheerbrant, A. (1988). Diccionario de los símbolos. Barcelona: Herder.

Durand, G. (1971). La imaginación simbólica. Buenos Aires: Amorrortu.

Durand, G. (1982). Las estructuras antropológicas de lo imaginario. Madrid: Taurus.

Dyer, R. (1993). The Matter of Images: Essays in Representation. Londres: Routledge.

Fernández, P. (1979). Estilística. Madrid: José Porrúa Turanzas.

Fernández, V. (2016, 6 de marzo). Las cartas de amor de Vicente Aleixandre a Carlos Bousoño. La Razón. http://www.larazon.es/cultura/musica/las-cartas-de-amor-devicente-aleixandre-a-carlos-bousono-DA12125798\#.Ttt1qjNspmwhpTh [Consulta 1 de abril 2017].

Forns-Broggi, R. (2012). Nudos como estrellas. ABC de la imaginación ecológica en nuestras Américas. Lima: Nido de Cuervos.

García-Barrientos, J. (2012). Cómo se comenta una obra de teatro. México: Paso de Gato.

Harris, D. (2005). Introducción. Por L. Cernuda. Un río, un amor; Los placeres prohibidos. (13-45). Madrid: Cátedra.

Kaylor, M. (2006). Secreted Desires: The Major Uranians: Hopkins, Pater and Wilde. Brno: Masaryk University Press.

López, M. (1992). Neologismos en la poesía de Vicente Aleixandre. Actas del II Congreso Internacional de Historia de la Lengua Española. (691-702). Madrid: Pabellón de España.

López-Casanova, A. (1994). El texto poético. Teoría y metodología. Salamanca: Colegio de España. 
Losada, J. (2013). Homopoética comparada: Al Berto y Jaime Gil de Biedma. Toledo: Celya.

Mateos-Miera, E. (2003). Máscara y verdad: identidades homoeróticas del 27. Orientaciones: revista de Homosexualidades. 6, 69-90.

Minkowski, E. (1999). Vers une cosmologie. París: Payot.

Mira, A. (2004). De Sodoma a Chueca. Una historia cultural de la homosexualidad en España en el siglo XX. Madrid: Egales.

Peratoner, A. (1892). Los peligros del amor, de la lujuria y del libertinaje en el hombre y en la mujer. Barcelona: s.n.

Pérez, M. (2001). Vicente Aleixandre, una visión poético-metafísica del amor. Didáctica. $13,263-284$.

Phillipps-López, D. (2002). (D)escribir la homosexualidad (algunos ejemplos modernistas). Boletín Hispánico Helvético. 0, 45-57.

Pihler, B. (2013). La temporalización discursiva en Historia del corazón de Vicente Aleixandre. Colindancias. 4, 275-288.

Prados, E. (1971). Cuerpo perseguido. Barcelona: Labor.

Rojas, P. (2012). "El gato de sí mismo", de Uriel Quesada: Novela de la travestización literaria. (Tesis de Maestría). Universidad de Costa Rica.

Spitzaer, L. (1961). La enumeración caótica en la poesía moderna. Lingüística e historia literaria. (247-291). Madrid: Gredos.

Tardieu, A. (1863). Estudio médico forense de los atentados contra la honestidad. Madrid: Imprenta médica de Manuel Álvarez.

Torras, M. (2007). El delito del cuerpo. De la evidencia del cuerpo al cuerpo en evidencia. Por M. Torras (Ed.). Cuerpo e identidad (I). (11-36). Barcelona: Edicions UAB. 
